\title{
The effects of personality and intention to act toward responsible environmental behavior
}

\author{
Riska Dian Pratiwi a,1, ${ }^{\text {, }}$ Rusdi a,2, Ratna Komala a,3 \\ a Department of Biology Education, Faculty of Mathematics and Natural Sciences, State University of Jakarta, J. Pemuda No. 10 \\ Rawamangun, East Jakarta, the Special Capital Territory of Jakarta (DKI, Jakarta) 13220, Indonesia \\ riskadian26@gmail.com*; ${ }^{2}$ rusdi@unj.ac.id; ${ }^{3}$ ratna_komala@yahoo.co.id \\ * corresponding author
}

\begin{tabular}{|c|c|}
\hline ARTICLE INFO & ABSTRACT \\
\hline $\begin{array}{l}\text { Article history } \\
\text { Received November 24, } 2018 \\
\text { Revised December 23, } 2018 \\
\text { Accepted February 23, } 2019 \\
\text { Published Maret 12, 2019 } \\
\text { Keywords } \\
\text { Intention to act } \\
\text { Personality } \\
\text { Responsible environmental } \\
\text { behavior }\end{array}$ & $\begin{array}{l}\text { Efforts to improve environmental responsibility are still being developed partially, in fact } \\
\text { this is the result of the interaction of various factors. This study aimed to investigate the } \\
\text { effect of personality and intention to act of the responsible environmental behavior. This } \\
\text { research was conducted at Senior High School Insan Cendekia Madani Boarding School } \\
\text { in the second semester of } 2017-2018 \text { academic year. The method used were survey with } \\
\text { quantitative-causal approach. This study used three variables i.e. personality (exogenous } \\
\text { variable/ } / X_{1} \text { ), intention to act (exogenous variable/ } X_{2} \text { ), and responsible environmental } \\
\text { behavior (endogenous variable } / X_{3} \text { ). The subject were } 90 \text { students from grade } X I \text { of } \\
\text { mathematics and science. The data analysis technique was used path analysis. Based } \\
\text { on hypothesis test conducted, the values of the path coefficient between } X_{1} \text { and } X_{2} \text { was } \\
0.385, X_{2} \text { and } X_{3} \text { was } 0.209, X_{1} \text { and } X_{3} \text { through } X_{2} \text { was } 0.08 \text {. The results showed that } \\
\text { there was significant indirect effect of personality to responsible environmental behavior } \\
\text { through the intention to act of Senior High School students. }\end{array}$ \\
\hline
\end{tabular}

Copyright $\odot 2019$, Pratiwi et al This is an open access article under the CC-BY-SA license
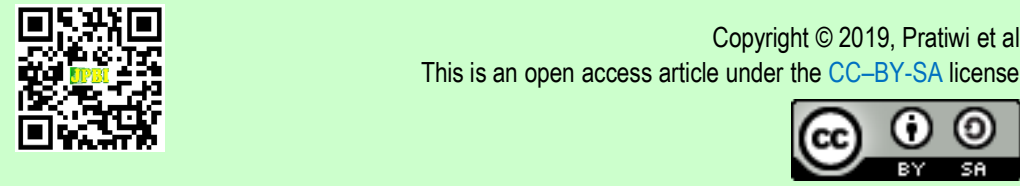

How to cite: Pratiwi, R. D., Rusdi, R., \& Komala, R. (2019). The Effects of personality and intention to act toward responsible environmental behavior. JPBI (Jurnal Pendidikan Biologic Indonesia), 5 (1), 169-176. doi: https://doi.org/10.22219/jpbi. v5i1.7120

\section{INTRODUCTION}

The problem of the threat of environmental damage (Barrow, Chan, \& Masron, 2010; Bullock \& O'Shea, 2016) and environmental change (Jawad, 2003; Marston, 2008) has developed into a topic that has been widely discussed in the past year. Several previous studies have reported that the problem of environmental damage and environmental changes leads to changes in ecosystem functions (Hines, Hungerford, \& Tomera, 1987; Tyagi, Garg, \& Paudel, 2014). Interestingly, this problem occurs in almost all countries both in the Continent of Europe (Wiessner et al., 2014), America (Beckett \& Keeling, 2019), Africa (Emeh \& Igwe, 2018; Oke, 2004), and Asia (Gu et al., 2017). This situation shows that environmental issue is not only a partial problem of a particular country but rather an unresolved global problem (Sadhu, Garg, \& Kumar, 2018; Thakur, 2016). 
Furthermore, the study revealed that these environmental changes stem from problems in environmental objects and subjects that are responsible for the sustainability of the environment itself (Brookfield, 1999). Various factors are indicated as triggers of environmental problems such as climate change (Blennow, Persson, Tomé, \& Hanewinkel, 2012; Clavero, Villero, \& Brotons, 2011), changes in natural resources (Jacobs \& Brown, 2014), technological change and development (Voulvoulis \& Burgman, 2019), the presence of pollution (Wiessner et al., 2014), and the most crucial factor is human activities (Li \& Wu, 2019). Human activities are said to be crucial factors due to their role as agents of environmental preservation (Short, 2009). This situation refers to the ability of humans to be responsible for efforts to manage and resolve current environmental problems (Rechkemmer \& Falkenhayn, 2009; Sadhu et al., 2018).

However, some previous studies reported different facts. The number of environmental cases departs from the low environmental responsibility so that it impacts on behavior that tends to be environmentally destructive (Gifford \& Nilsson, 2014; Lahsen et al., 2010; Urien \& Kilbourne, 2011). Therefore, efforts are relevant in overcoming various environmental problems by changing behavior and human responsibility itself (Gifford, Steg, \& Reser, 2012; Manning, 2009). From various related domains, education is identified as one way to change destructive behavior by fostering environmental attitudes and responsibilities (Boyes \& Stanisstreet, 2012; Desfandi, 2015). Strengthening personalities through education is indicated as being able to shape and foster the values of environmental responsibility in the community. As previously explained, environmental responsibility is closely related to various factors and conditions, i.e. socio-economic (Ngwaru \& Opoku-Amankwa, 2010; Thakur, 2016), socio-ecology (Rechkemmer \& Falkenhayn, 2009), and socio-cognitive (Desfandi, 2015).

Education is identified as one of the effective ways to grow a socio-cognitive society. Furthermore, many researchers developed environment-based learning models (Boyes \& Stanisstreet, 2012; Gifford \& Nilsson, 2014). The environmental education model began in the 1970s which assumed several types of linear relationships between attitudes and behavior, where positive attitudes lead to positive behavior (Kollmuss \& Agyeman, 2002; Ralston \& Martin, 1970). In this case, all actions aimed at restoring and preventing the environment from the threat of damage are an integral part of the responsible environmental behavior (REB) (Adams, 2003; Short, 2009). The model described by Hines et al. (1987) revealed that environmental responsibility behavior was determined by various situational factors such as personality and intention to act. Situational factors are driven by the individual's view of a matter, while the intention to act is influenced by personality and knowledge (Gifford \& Nilsson, 2014).

However, in reality, information describing how the pattern of relationships between personality and intention to act on attitudes and responsibilities in the environment has not been widely discussed, but both are discussed more partially (Boyes \& Stanisstreet, 2012; Kvasova, 2015; Yu \& Yu, 2017). This study aims to determine the extent to which personality has an impact on students' intention to act in developing an environmentally responsible attitude.

\section{METHOD}

This quantitative research used a causal survey method. This study used path analysis to determine the pattern of relationships between variables in order to determine the direct or indirect effects between exogenous and endogenous variables. The study was conducted at Senior High School (SHS) of Insan Cendekia Madani in the odd semester of academic year 2018/2019. The target population in this study were all students of Insan Cendekia Madani. The research sampling technique was simple random sampling and was taken by 90 students' grade XI science. The sample was tested using the McClave formula to determine the minimum sample. Furthermore, the path analysis design is explained in Figure 1.

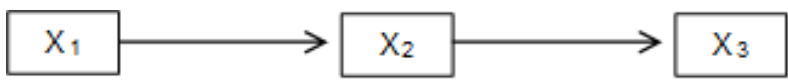

Figure 1. Path analysis model

Data collection techniques were compiled using a descriptive personality scale developed by Han and Pistole (2017) through the dimensions of experience, consciousness, extraversion, agreeableness, and neuroticism. Intention to act was prepared using a descriptive scale with indicators: managing the environment well, complying with environmental rules, utilizing natural resources in a controlled manner, choosing and caring for environmentally friendly technologies, and maintaining natural resources to ensure the life of present and future generations.

REB instrument used dimensions of eco-management, consumerism, persuasion, and political actions (Hungerford \& Volk, 1990). The grid of instruments that measure personality was presented in Table 1. Instrument 
intention to act used dimensions the desire to protect the environment, the desire to preserve the environment, the desire to utilize natural resources (Kaiser \& Shimoda, 1999). The validated instrument personality, intention to act and environmental responsibility behavior was used by the Pearson product moment. The instrument items are declared valid if the number of $R_{\text {table }}$ is higher than the table according to the predetermined significance level $(a=0.05)$. Reliability was a calculated of the consistency of instrument data used the Cronbach-alpha.

The prerequisite test used the Kolmogorov-Smirnov normality test $(\alpha=0.05)$ using the SPSS 24.0 program. Test of significance and linearity regression using the F-test, calculation of the correlation coefficient using the Pearson product moment. The significance test results of the correlation coefficient with the t-test are then continued using path analysis.

Table 1. The measure of personality

\begin{tabular}{|c|c|c|c|c|c|}
\hline \multirow{2}{*}{ No } & \multirow{2}{*}{ Dimension } & \multirow{2}{*}{ Indicator } & \multicolumn{2}{|c|}{ Number of items } & \multirow{2}{*}{ Total } \\
\hline & & & + & - & \\
\hline \multirow{3}{*}{1.} & & & 1,3 & 6,8 & 12 \\
\hline & Openness ( 0 ) & Action, ideas, values. & 5,12 & 2,4 & \\
\hline & & & 9,11 & 7,13 & \\
\hline \multirow{3}{*}{2.} & & & 10,14 & 17,19 & 12 \\
\hline & Conscientiousness $(\mathrm{C})$ & Order, self-discipline, deliberation. & 15,18 & 20,22 & \\
\hline & & & 21,24 & 16,23 & \\
\hline \multirow{3}{*}{3.} & & & 25,27 & 29,31 & 12 \\
\hline & Extraversion $(\mathrm{E})$ & Assertiveness, activity, positive emotions. & 28,30 & 26,32 & \\
\hline & & & 33,35 & 37,38 & \\
\hline \multirow{3}{*}{4.} & & & 34,36 & 39,41 & 12 \\
\hline & Agreeableness (A) & Trust, modesty, tender-mindedness. & 42,44 & 40,46 & \\
\hline & & & 43,45 & 47,49 & \\
\hline \multirow{3}{*}{5.} & & & 48,50 & 52,54 & 12 \\
\hline & Neuroticism (N) & Anxiety, emotion, self-consciousness. & 51,53 & 55,57 & \\
\hline & & & 56,58 & 59,60 & \\
\hline & & Total & & & 60 \\
\hline
\end{tabular}

\section{RESULTS AND DISCUSSION}

The Kolmogorov-Smirnov normality test results on personality variables $\left(X_{1}\right)$ were 0.166 . While the significance value of the intention variable to act $\left(\mathrm{X}_{2}\right)$ and the responsible environmental behavior (REB) are respectively 0.92 and 0.068 . Thus, the significance of the three variables $(>0.05)$ so that it can be concluded that the data comes from populations that are normally distributed. Based on the results of the calculation of data to compile a regression equation model between personality and intention to act in a row of 45.51 and 0.409 . The regression equation between personality variables and the intention to act is $X_{3}=45.51+0.409 X_{1}$. Regression calculations as described in Table 2.

Table 2. Results of regression equation between the personality and intention to act.

\begin{tabular}{|c|c|c|c|c|c|}
\hline \multicolumn{6}{|c|}{ Coefficients $^{\mathrm{a}}$} \\
\hline \multirow{2}{*}{ Model } & \multicolumn{2}{|c|}{ Unstandardized Coefficients } & \multirow{2}{*}{$\frac{\text { Standardized Coefficients }}{\text { Beta }}$} & \multirow{2}{*}{$\mathbf{t}$} & \multirow{2}{*}{ Sig. } \\
\hline & B & Std. Error & & & \\
\hline (Constant) & 45.510 & 8.215 & & 5.540 & .000 \\
\hline Personality & .409 & .104 & .386 & 3.921 & .004 \\
\hline
\end{tabular}

Based on Table 3, the regression equation between personality and REB is $X_{3}=52.282+0.338 X_{1}$. The coefficient indicates that the equation can be trusted because it has a significance value $(>0.05)$. While the regression between intention to act against REB (Table 4) is written with the equation $X_{3}=55.238+0.303 X_{2}$ with significance value $(<0.05)$. This results showed that intention to act influences students REB.

Table 3. Results of calculation of the equations of personality regression and REB

\begin{tabular}{ccccccc}
\hline \multicolumn{7}{c}{ Coefficients $^{\mathbf{a}}$} \\
\hline \multirow{2}{*}{ Model } & \multicolumn{2}{c}{ Unstandardized Coefficients } & $\begin{array}{c}\text { Standardized } \\
\text { Coefficients }\end{array}$ & t & Sig. \\
\cline { 2 - 6 } & $\mathrm{B}$ & Std. Error & Beta & & 6.131 & .000 \\
(Constant) & 52.282 & 8.528 & .315 & 3.117 & .002 \\
\hline Personality & .338 & .108 & & .317 \\
\hline
\end{tabular}


Table 4. Results of calculation of the equations of intention to act regression and REB

\begin{tabular}{ccccccc}
\hline \multicolumn{7}{c}{ Coefficients $^{\mathbf{a}}$} \\
\hline & \multicolumn{7}{c}{ Unstandardized Coefficients } & Standardized Coefficients & & \\
\cline { 2 - 7 } Model & $\mathrm{B}$ & Std. Error & Beta & $\mathrm{t}$ & Sig. \\
\hline (Constant) & 55.238 & 8.001 & .904 & .000 \\
Intention to Act & .303 & .103 & .300 & 2.952 & .004 \\
\hline
\end{tabular}

Based on the results of the significance test, the regression line equation between personality and intention to act shows the calculated $F_{\text {value }}$ of 3.921 with a significance value of $(<0.05)$. Thus, the equation is a significant variable or shows the influence of personality on the intention to act. Similar results are also shown for the regression equation intention to act on $\operatorname{REB}\left(X_{2}\right.$ against $\left.X_{3}\right)$ and personality towards $\operatorname{REB}\left(X_{1}\right.$ against $\left.X_{3}\right)$. The test of the significance of the equality of intention to act on REB shows $F_{\text {value }}$ of 2.592 with a significance of 0.004 while the calculated $F_{\text {value }}$ for personality equation towards REB is 3.117 with a significance of 0.002 . These results indicate that there is a significant relationship between intention to act with REB, as well as the relationship between personality and REB. The results of the calculation of the correlation test between variables in this study obtained data as in Table 5.

Table 5. Simple correlation coefficient matrix between variables

\begin{tabular}{cccc}
\hline \multirow{2}{*}{ Matrix } & \multicolumn{3}{c}{ Coefficient of correlation $(\alpha=0,00)$} \\
\cline { 2 - 4 } & $X_{1}$ & $X_{2}$ & $X_{3}$ \\
\hline$X_{1}$ & 1 & 0,386 & 0,300 \\
$X_{2}$ & & 1 & 1 \\
$X_{3}$ & & & 1 \\
\hline
\end{tabular}

The correlation coefficient matrix between variables found a correlation between personality and intention to act was $R_{1,2}=0.386$, while the correlation between intention to act and REB was $R_{2,3}=0.300$. After each correlation coefficient was obtained, the next step is to calculate the path coefficient. Direct and indirect effects described in Table 6.

Table 6. Results of calculation of direct and indirect effects

\begin{tabular}{cccccc}
\hline $\begin{array}{c}\text { Direct influence between } \\
\text { variables }\end{array}$ & $\begin{array}{c}\text { Path coefficient } \\
(\mathrm{Pij})\end{array}$ & $\begin{array}{c}\text { Standard error } \\
(\text { Sbi) }\end{array}$ & tvalue & $t_{\text {table }}$ & Conclusion \\
\hline $\mathrm{X}_{1}$ and $\mathrm{X}_{2}$ & 0.386 & 0.098 & 3.921 & 1,662 & Significant \\
$\mathrm{X}_{2}$ and $\mathrm{X}_{3}$ & 0.209 & 0.105 & 1.981 & 1,662 & Significant \\
\hline
\end{tabular}

Based on the results of the correlation test in Table 6, the personality variable and intention to act is 0.386 with a significance value $(<0.05)$, so the correlation between personality and intention to act is significant. Meanwhile, the path analysis coefficient showed that tvalue $(3,921)>t_{\text {table }}(1,662)$ so that the intention variable to act is directly influenced positively by personality. These results indicate that the positive personality of students indicates the tendency of students to act positively towards the environment better. The results are relevant to the research proposed by $\mathrm{Yu}$ and $\mathrm{Yu}$ (2017) which states that personality has a positive influence on one's willingness to act on the environment. In different definitions, it can be said that in carrying out an action someone refers to his personality (Hines et al., 1987). Environmental responsibility develops according to the knowledge, attitudes, and skills possessed by each. These three components develop in the cognitive structure of students according to their age, experience, gender differences, and perceptions of environmental problems (Gifford \& Nilsson, 2014; Short, 2009).

The results of the intention correlation coefficient to act on REB showed the same results with the correlation between personality and intention to act. Based on the results of the coefficient calculation (Table 5) shows that $t_{\text {value }}(1.981)>t_{\text {table }}(1.662)$. These results indicate that student responsible behavior is positively influenced by the intention to act. At least, there are three variables in the self that influence the decision to act, including attitudes toward certain behaviors, subjective norms, and perceptions of behavioral control (Sawitri, Hadiyanto, \& Hadi, 2015). Mancha and Yoder (2015) explained in his research that the intention to act as a predictor of REB. Thus, a positive relationship between personality and intention to act can indicate that students tend to be able to take actions aimed at protecting the environment in their daily lives (Ojedokun \& Balogun, 2010).

However, the path coefficient of the indirect effect of personality variables on REB is 0.08 . This result shows that personality does not directly affect the student's behavior but through the intention to act. Contextually, it can be said that if the students have a positive personality, indirectly, these students have environmental responsibility because they have the intention to act well. Han and Pistole (2017); Kvasova (2015) Suggests that individual characters such as personality can influence one's actions through various mechanisms carried out by 
individuals, one of which is the intention to act. Each has the character that can distinguish itself from other individuals. Through various mechanisms or intermediaries, the individual can show the behavior he wants to do.

The various personality factors influence behavior to be environmentally responsible. This personality factor determines someone to act and take a role in protecting and preserving the environment (Adams, 2003; Costa \& McCrae, 2012). Besides, it was strengthened on the findings made by Ajzen and Manstead (2007) that the desire to act someone becomes a determinant in behaving environmentally responsible. Personality factors that play an important role in the decision include experience in childhood, level of knowledge and education, gender, age, and daily activities are undertaken (Gifford \& Nilsson, 2014). Some observable impacts as indicators of the growth of environmental responsibility of students include being actively involved in activities with environmental issues, merging in community-based activities rather than individual efforts, changing the behavior of consumerism that is more environmentally friendly, sensitive to issues of changing ecosystem functions, and other behaviors which is specifically related to their daily activities (Hines et al., 1987; Hungerford \& Volk, 1990; Short, 2009). However, as discussed earlier, the five indicators of environmental responsibility do not necessarily grow but need a conducive learning culture so that students' cognitive is deliberately conditioned to be able to involve deeper thinking skills so that they can make decisions and be responsible for the environment around it comprehensively.

Several studies have reported that efforts to induce environmental responsibility have been carried out including by implementing the good sustainability campaign (Font \& McCabe, 2017; Laurie, Nonoyama-Tarumi, Mckeown, \& Hopkins, 2016; Leal Filho et al., 2018; Manning, 2009; Mapotse \& Mashiloane, 2017; Schultze \& Trommer, 2012), environmental and social responsibility education (Aguado \& Holl, 2018), and adiwiyata school program (Desfandi, 2015). All the programs have similarities in terms of community involvement and society. Community involvement is a strategic effort to create a mutually supportive and sustainable environment (Gifford \& Nilsson, 2014; Kvasova, 2015). On the other hand, this effort is indicated to be able to improve socio-cognitive which has an essential role in determining the desired environmental responsibility (Sawitri et al., 2015). Social aspects are very fundamental because in some studies it was reported that the appearance of attitudes is not directly influenced by behavior but rather on intentions that end at the norms that apply to the community (Kollmuss \& Agyeman, 2002).

Therefore, the results of this study can be used as reinforcement of the concepts that have been believed. However, it is necessary to develop more specific personality factors that have the most influence on students' responsibility for the environment. Furthermore, how to integrate learning that can grow and harmonize the personality and intention to act responsibly.

\section{CONCLUSION}

The research results have shown that there is a direct influence between the personality and intention to act and between the intention to act on the responsible environmental behavior. Meanwhile, the personality affects REB indirectly through the intention to act. Based on the results of the study, it needs a systematic effort to improve the behavior of students' environmental responsibility through the learning process that is integrated into the subjects. It is intended that students are able to grow personality and have good point of views about management and environmental responsibility. In addition, the school needs to involve students actively to participate in every activity at school and outside the school related to the environment.

\section{ACKNOWLEDGEMENT}

Our highest appreciation is addressed to all parties involved in this study, including the Department of Biology Education, Dean of Faculty of Mathematics and Natural Sciences, State University of Jakarta, Principal and Teachers of Senior High School Insan Cendekia Madani Tangerang - Banten, as well as all the students whom participated in this research.

\section{REFERENCES}

Adams, W. J. (2003). Promoting environmentally responsible behaviour: An evaluation of the global learning and observations to benefit the environment (GLOBE) programme. Retrieved from https://core.ac. uk/download/pdf/43164870.pdf

Aguado, E., \& Holl, A. (2018). Differences of corporate environmental responsibility in small and medium enterprises: Spain and Norway. Sustainability, 10(6), 1877. doi: https://doi.org/10.3390/su10061877

Ajzen, I., \& Manstead, A. S. R. (2007). Changing health-related behaviours: An approach based on the theory 
pf planned behaviour. In The Scope of Social Psychology: Theory and Applications (pp. 43-64). New York: Psychology Press. Retrieved from https://www.researchgate.net/profile/lvo_De_Sousa/post/What_ theories_which_can_support_studies_on_a_groups_psyche/attachment/59d61e5079197b807797cb83/ AS\%3A277446856331275\%401443159893963/download/The_Scope_of_Social_Psychology_Theory and_Applications.pdf

Barrow, C. J., Chan, N. W., \& Masron, T. Bin. (2010). Farming and other stakeholders in a tropical highland: Towards less environmentaly damaging and more sustainable practices. Journal of Sustainable Agriculture, 34(4), 365-388. doi: https://doi.org/10.1080/10440041003680205

Beckett, C., \& Keeling, A. (2019). Rethinking remediation: Mine reclamation, environmental justice, and relations of care. Local Environment, 24(3), 216-230. doi: https://doi.org/10.1080/13549839.2018.1557127

Blennow, K., Persson, J., Tomé, M., \& Hanewinkel, M. (2012). Climate change: Believing and seeing implies adapting. PLoS ONE, 7(11), 1-7. doi: https://doi.org/10.1371/journal.pone.0050182

Boyes, E., \& Stanisstreet, M. (2012). Environmental education for behaviour change: Which actions should be targeted? International Journal of Science Education, 34(10), 1591-1614. doi: https://doi.org/10.1080/ 09500693.2011.584079

Brookfield, H. (1999). Environmental damage: distinguishing human from geophysical causes. Environmental Hazards, 1(1), 3-11. doi: https://doi.org/10.3763/ehaz.1999.0102

Bullock, C., \& O'Shea, R. (2016). Valuing environmental damage remediation and liability using value estimates for ecosystem services. Journal of Environmental Planning and Management, 59(9), 1711-1727. doi: https://doi.org/10.1080/09640568.2015.1085842

Clavero, M., Villero, D., \& Brotons, L. (2011). Climate change or land use dynamics: Do we know what climate change indicators indicate? PLOS ONE, 6(4), 1-8. doi: https://doi.org/10.1371/journal.pone.0018581

Costa, P. T., \& McCrae, R. R. (2012). The five-factor model and the NEO inventories. Oxford Handbook of Personality Assessment, (December). doi: https://doi.org/10.1093/oxfordhb/9780195366877.013.0016

Desfandi, M. (2015). Mewujudkan masyarakat berkarakter peduli lingkungan melalui program adiwiyata. SOSIO DIDAKTIKA: Social Science Education Journal, 2(1), 31-37. doi: https://doi.org/10.15408/sd.v2i1.1661

Emeh, C., \& Igwe, O. (2018). Effect of environmental pollution on susceptibility of sesquioxide-rich soils to water erosion. Geology, Ecology, and Landscapes, 9508, 1-12. doi: https://doi.org/10.1080/24749508.2018. 1452484

Font, X., \& McCabe, S. (2017). Sustainability and marketing in tourism: Its contexts, paradoxes, approaches, challenges and potential. Journal of Sustainable Tourism. doi: https://doi.org/10.1080/09669582.2017. 1301721

Gifford, R., \& Nilsson, A. (2014). Personal and social factors that influence pro-environmental concern and behaviour: A review. International Journal of Psychology, 49(3). doi: https://doi.org/10.1002/ijop.12034

Gifford, R., Steg, L., \& Reser, J. P. (2012). Environmental psychology. In Encyclopedia of Human Behavior (pp. 54-60). Elsevier. doi: https://doi.org/10.1016/B978-0-12-375000-6.00150-6

Gu, C., Mu, X., Gao, P., Zhao, G., Sun, W., \& Li, P. (2017). Effects of climate change and human activities on runoff and sediment inputs of the largest freshwater lake in China, Poyang Lake. Hydrological Sciences Journal, 6667(September). doi: https://doi.org/10.1080/02626667.2017.1372856

Han, S., \& Pistole, M. C. (2017). Big five personality factors and facets as predictors of openness to diversity. Journal of Psychology: Interdisciplinary and Applied, 151(8), 752-766. doi: https://doi.org/10.1080/ 00223980.2017 .1393377

Hines, J. M., Hungerford, H. R., \& Tomera, A. N. (1987). Analysis and synthesis of research on responsible environmental behavior: A meta-analysis. The Joumal of Environmental Education, 18(2), 1-8. doi: https: //doi.org/10.1080/00958964.1987.9943482

Hungerford, H. R., \& Volk, T. L. (1990). Changing learner behavior through environmental education. The Journal of Environmental Education, 21(3), 8-21. doi: https://doi.org/10.1080/00958964.1990.10753743

Jacobs, B. C., \& Brown, P. R. (2014). Drivers of change in landholder capacity to manage natural resources. Journal of Natural Resources Policy Research, 6(1), 1-26. doi: https://doi.org/10.1080/19390459.2013. 869032

Jawad, L. A. (2003). Impact of environmental change on the freshwater fish Fauna of Iraq. International Journal of Environmental Studies, 60(6), 581-593. doi: https://doi.org/10.1080/0020723032000087934

Kaiser, F. G., \& Shimoda, T. A. (1999). Responsibility as a predictor of ecological behaviour. Journal of Environmental Psychology, 19(3), 243-253. doi: https://doi.org/10.1006/jevp.1998.9123

Kollmuss, A., \& Agyeman, J. (2002). Mind the gap: Why do people act environmentally and what are the barriers 
to pro-environmental behavior? Environmental Education Research, 8(3), 239-260. doi: https://doi.org/10.1080/13504620220145401

Kvasova, O. (2015). The big five personality traits as antecedents of eco-friendly tourist behavior. Personality and Individual Differences, 83, 111-116. doi: https://doi.org/10.1016/j.paid.2015.04.011

Lahsen, M., Sanchez-Rodriguez, R., Lankao, P. R., Dube, P., Leemans, R., Gaffney, O., ... Smith, M. S. (2010). Impacts, adaptation and vulnerability to global environmental change: challenges and pathways for an action-oriented research agenda for middle-income and low-income countries. Current Opinion in Environmental Sustainability, 2(5-6), 364-374. doi: https://doi.org/10.1016/j.cosust.2010.10.009

Laurie, R., Nonoyama-Tarumi, Y., Mckeown, R., \& Hopkins, C. (2016). Contributions of education for sustainable development (ESD) to quality education: A synthesis of research. Journal of Education for Sustainable Development, 10(2), 226-242. doi: https://doi.org/10.1177/0973408216661442

Leal Filho, W., Raath, S., Lazzarini, B., Vargas, V. R., de Souza, L., Anholon, R., ... Orlovic, V. L. (2018). The role of transformation in learning and education for sustainability. Journal of Cleaner Production, 199, 286-295. doi: https://doi.org/10.1016/j.jclepro.2018.07.017

Li, P., \& Wu, J. (2019). Sustainable living with risks: meeting the challenges. Human and Ecological Risk Assessment: An International Journal, O(0), 1-10. doi: https://doi.org/10.1080/10807039.2019.1584030

Mancha, R. M., \& Yoder, C. Y. (2015). Cultural antecedents of green behavioral intent: An environmental theory of planned behavior. Journal of Environmental Psychology, 43, 145-154. doi: https://doi.org/10.1016 /j.jenvp.2015.06.005

Manning, C. (2009). The psychology of sustainable behavior: Tips for empowering people to take environmentally positive action. Minnesota Pollution Control Agency. Retrieved from http://www.pca.state.mn.us/index.php/view-document.html?gid=12949\%5Cnhttp://www.pca.state.mn.us /index.php/topics/preventing-waste-and-pollution/sustainability/sustainable-communities/psychology-ofsustainable-behavior.html

Mapotse, T. A., \& Mashiloane, T. K. (2017). Nurturing learners' awareness of littering through environmental campaigns: An action research approach. Eurasia Journal of Mathematics, Science and Technology Education, 13(10), 6909-6921. doi: https://doi.org/10.12973/ejmste/76658

Marston, R. A. (2008). Land, life, and environmental change in mountains. Annals of the Association of American Geographers, 98(3), 507-520. doi: https://doi.org/10.1080/00045600802118491

Ngwaru, J. M., \& Opoku-Amankwa, K. (2010). Home and school literacy practices in Africa: Listening to inner voices. Language and Education, 24(4), 295-307. doi: https://doi.org/10.1080/09500781003678985

Ojedokun, A. O., \& Balogun, S. (2010). Environmental attitude as a mediator of the relationship between selfconcept, environmental self-efficacy and responsible environmental behaviour among residents of high density areas in Ibadan Metropolis, Nigeria. Ethiopian Journal of Environmental Studies and Management, 3(2), 111-119. doi: https://doi.org/10.4314/ejesm.v3i2.59834

Oke, S. A. (2004). On the environmental pollution problem : A review. Journal of Environmental Engineering and Landscape Management, 12(3), 108-113. doi: https://doi.org/10.1080/16486897.2004.9636828

Ralston, N. P., \& Martin, I. R. (1970). A cross cultural environmental education model. Environmental Education, 2(2), 32-35. doi: https://doi.org/10.1080/00139254.1970.10801551

Rechkemmer, A., \& Falkenhayn, L. von. (2009). The human dimensions of global environmental change: Ecosystem services, resilience, and governance. The European Physical Journal Conferences, 1, 3-17. doi: https://doi.org/10.1140/epjconf/e2009-00906-y

Sadhu, S. D., Garg, M., \& Kumar, A. (2018). Major environmental issues and new materials. In New Polymer Nanocomposites for Environmental Remediation (pp. 77-97). Elsevier. doi: https://doi.org/10.1016/B9780-12-811033-1.00004-4

Sawitri, D. R., Hadiyanto, H., \& Hadi, S. P. (2015). Pro-environmental behavior from a socialcognitive theory perspective. In Procedia Environmental Sciences (Vol. 23, pp. 27-33). Elsevier B.V. doi: https://doi. org/10.1016/j.proenv.2015.01.005

Schultze, W., \& Trommer, R. (2012). The concept of environmental performance and its measurement in empirical studies. Journal of Management Control. doi: https://doi.org/10.1007/s00187-011-0146-3

Short, P. C. (2009). Responsible environmental action : Its role and status in environmental education and environmental quality. The Journal of Environmental Education, 41(1), 7-21. doi: https://doi.org/10.10 80/00958960903206781

Thakur, B. K. (2016). Impact of environmental degradation on human health. In International Research Journal of Management, IT \& Social Sciences (Vol. 3, p. 1). New Century Publications. doi: https://doi.org/10.217 


\section{4/irjmis.v3i1.82}

Tyagi, S., Garg, N., \& Paudel, R. (2014). Environmental degradation: Causes and consequences. European Researcher, 81(8-2), 1491. doi: https://doi.org/10.13187/er.2014.81.1491

Urien, B., \& Kilbourne, W. (2011). Generativity and self-enhancement values in eco-friendly behavioral intentions and environmentally responsible consumption behavior. Psychology and Marketing, 28(1), 6990. doi: https://doi.org/10.1002/mar.20381

Voulvoulis, N., \& Burgman, M. A. (2019). Technology The contrasting roles of science and technology in environmental challenges environmental challenges. Critical Reviews in Environmental Science and Technology, 0(0), 1-28. doi: https://doi.org/10.1080/10643389.2019.1565519

Wiessner, A., Müller, J. A., Kuschk, P., Kappelmeyer, U., Kästner, M., Liu, Y.-J., \& Stottmeister, U. (2014). Environmental pollution by wastewater from brown coal processing - a remediation case study in Germany. Journal of Environmental Engineering and Landscape Management, 22(1), 71-83. doi: https://doi.org/10.3846/16486897.2013.808640

Yu, T.-Y., \& Yu, T.-K. (2017). The moderating effects of students' personality traits on pro-environmental behavioral intentions in response to climate change. International Journal of Environmental Research and Public Health, 14(12), 1472. doi: https://doi.org/10.3390/ijerph14121472 